\title{
Tanggung Jawab Direksi Perseroan Terbatas dalam Pelanggaran Fiduciary Duty
}

\author{
Siti Hapsah Isfardiyana*
}

\begin{abstract}
Abstrak
Direksi merupakan organ perseroan terbatas yang bertanggungjawab terhadap pengurusan dan perwakilan perseroan, sesuai maksud dan tujuan perseroan berdasarkan angaran dasar rumah tangga perseroan terbatas. Pengurusan dan perwakilan oleh direksi harus dijalankan sesuai prinsip fiduciary duty.Tulisan ini menekankan pada persoalan kecerobohan direksi sehingga melakukan pelanggaran fiduciary duty, yang berakibat pada penerapan piercing the coporate veil pada direksi. Dasar hukum utama yang digunakan dalam penelitian ini termasuk Kitab Undang-Undang Hukum Perdata (KUHP) dan Undang-Undang Nomor 40 Tahun 2007 tentang Perseroan Terbatas. Direksi dalam menjalankan kepengurusannya harus didasarkan dengan itikad baik dan penuh tanggung jawab karena direksi memegang fiduciary duty dari perseroan. Apabila direksi lalai dalam tugasnya, direksi dapat dikenakan piercing the corporate veil yaitu pertanggungjawaban pribadi sampai kepada harta pribadi direksi atas kerugian yang diterima oleh perseroan, pemegang saham, atau pihak ketiga. Hal ini digunakan untuk melindungi kepentingan pemegang saham atau pihak ketiga yang dirugikan atas tindakan direksi yang sewenang-wenang atau tidak layak yang dilakukan atas nama perseroan.
\end{abstract}

Kata kunci: perseroan, direksi, tanggung jawab direksi, fiduciary duty, piercing the corporate veil.

\section{Responsibility of The Company's Directors Regarding Breach of Fiduciary Duty}

\begin{abstract}
The company's directors is the organ responsible for the maintenance and as a representative of the company based on the purpose and objectives of the articles of association. Management and representation by the directors must be executed according to the principle of fiduciary duty. This study emphasized the issue of directors' negligence that leads to the breach of fiduciary duty, which results to the application of piercing the corporate veil by the directors. Primary legal materials used in this study including the Code of Civil Law (Civil Code) and Law No. 40 of 2007 on Limited Company. The directors should be implemented in good faith and full responsibility in carrying out its duty, because the directors hold fiduciary duty of the company. If the directors failed to perform their duties, they may be subject to piercing the corporate veil which is personal accountability by the directors up until their personal property regarding the loss received by the company,
\end{abstract}

PADJADJARAN Jurnal IImu Hukum Volume 2 Nomor 1 Tahun 2015 [ISSN 2460-1543] [e-ISSN 2442-9325]

* Dosen Tetap Fakultas Hukum Universitas Islam Indonesia, Jl. Tamansiwa No. 158 Yogyakarta 55151, dianhapsah@gmail.com, S.H. (Universitas Islam Indonesia), M.H. (Universitas Islam Indonesia). 
shareholders or stakeholder. It is applied to protect the interests of shareholders or third parties that have been harmed by the actions taken arbitrary by the directors or improper conduct on behalf of the company.

Keywords: company, directors, directors responsibility, fiduciary duty, piercing the corporate veil.

\section{A. Pendahuluan}

Perseroan terbatas (perseroan) adalah subjek hukum yang tidak berjiwa dan ada karena diciptakan oleh manusia (artificial person). Posisi perseroan sebagai subjek hukum memberikan kedudukan perseroan sama seperti manusia pada umumnya dalam bidang hukum. Perseroan dapat melakukan perbuatan hukum, menuntut atau dituntut di pengadilan. Perseroan tidak mempunyai jiwa sehingga harus membentuk pengurus perseroan agar perseroan dapat menjadi subjek hukum seutuhnya. Pengurus perseroan akan menjadi organ perseroan yang bertugas membantu perseroan untuk memperoleh hak dan menjalankan kewajiban perseroan. Adapun organ perseroan terdiri dari Rapat Umum Pemegang Saham (RUPS), direksi, dan komisaris.

Pada hukum perseroan Indonesia, dianut prinsip limited liability dan separate entity. Perseroan mempunyai wujud atau entitas (entity) yang terpisah dan berbeda dari pemlikinya, yang dalam hal ini terpisah dari pemegang saham (separate and distinct from its owner). ${ }^{1}$ Kekayaan perseroan tidak dapat dimiliki atau dikuasai oleh para pemegang saham. Pegang saham tidak berhak mengalihkan harta kekayaan perseroan kepada pihak ketiga. Entitas terpisah (separate entity) memberikan keleluasaan kepada perseroan dari tekanan dan penyalahgunaan pemegang saham. Kekayaan yang dimiliki perseroan menjadi tanggung jawab dan milik perseroan sepenuhnya. Hal tersebut membuat kewajiban yang timbul atas kerugian yang diterima perseroan menjadi tanggungjawab perseroan, bukan pendiri atau pengurus perseroan yang diambil dari kekayaan perseroan.

Limited liability atau tanggung jawab yang terbatas adalah tanggung jawab pendiri dan pengurus perseroan yang terbatas pada modal yang disetor. Pemegang saham perseroan tidak bertanggung jawab secara pribadi atas perikatan yang dibuat atas nama perseroan dan tidak bertanggung jawab atas kerugian perseroan melebihi saham yang dimiliki. ${ }^{2}$ Pemegang saham hanya bertanggung jawab sebatas modal yang telah disetor kepada perseroan dan tidak melebihi modal yang telah disetor dan tidak dapat diminta pertanggungjawabannya atas apa yang telah

\footnotetext{
1 M. Yahya Harahap, Hukum Perseroan, Catakan Ketiga, Edisi Ketujuh, Jakarta: Sinar Grafika, 2011, hlm. 57.

2 Pasal 3 ayat (1) Undang-Undang Nomor 40 Tahun 2007 tentang Perseroan Terbatas.
} 
diperbuat oleh perseroan. Harta pribadi pemegang saham tidak dapat diminta untuk dijadikan pertanggungjawaban perseroan.

Limited liability tidak hanya berlaku bagi pemegang saham tetapi juga berlaku bagi organ perseroan yang lainnya yaitu direksi dan komisaris. Direksi dan komisaris harus melakukan semua tugasnya sesuai dengan kewenangan yang diberikan oleh peraturan perundang-undangan dan Angggaran Dasar Rumah Tangga Perseroan Terbatas (ADRT PT). Jadi organ perseroan yang beritikad baik dalam menjalankan tugas dan wewenangnya tidak dapat dimintai pertangggungjawaban atas kerugian yang diterima perseroan atau pihak ketiga. Tidak selamanya limited liability dapat dilakukan karena adanya suatu sebab. Terbatasnya tanggung jawab perseroan terkoyak dengan prinsip piercing the corporate veil. Organ perseroan akan dimintai pertanggungjawaban jika organ tersebut bertindak melebihi wewenangnya atau telah berbuat lalai atau sengaja sehingga perseroan atau pihak lain mengalami kerugian.

Organ perseroan yang memegang posisi sangat penting adalah direksi. Pada Pasal 1 angka 5 Undang-Undang Nomor 40 Tahun 2007 tentang Perseroan Terbatas (UU PT) disebutkan bahwa direksi suatu perseroan berwenang dan bertanggung jawab penuh atas pengurusan perseroan untuk kepentingan perseroan, sesuai dengan maksud dan tujuan perseroan serta mewakili perseroan, baik di dalam maupun di luar pengadilan sesuai dengan ketentuan anggaran dasar. Maju dan berkembangnya perseroan ditentukan oleh direksi. Direksi menjadikan perseroan hidup, tanpa direksi perseroan tidak dapat menjalankan kewajibannya. Segala hal yang berhubungan dengan kegiatan perseroan dijalankan oleh direksi.

Tugas direksi didasarkan pada doktrin fiduciary duty. Doktrin fiduciary duty berasal dari sistem hukum Common Law yang mengajarkan bahwa antar direksi dengan perseroan terdapat hubungan fiduciary. Direksi hanya bertindak seperti sprang trustee atau agen semata-mata, yang mempunyai kewajiban mengabdi sepenuhnya dan dengan sebaik-baiknya kepada perseroan. ${ }^{3}$ Direksi dituntut harus dapat mempunyai kepedulian dan kemampuan (duty of care and skill), itikad baik, loyalitas, dan kejujuran terhadap perusahaannya dengan derajat yang tinggi (high degree). ${ }^{4}$

Kepercayaan yang diberikan oleh perseroan tersebut harus dijalankan sesuai dengan peraturan perundang-undangan dan ADRT PT. Direksi yang menjalankan kepengurusan perseroan di dalam garis yang telah ditentukan, tidak dapat dimintai pertanggungjawaban. ${ }^{5}$ Hal ini berakibat direksi tidak dapat dimintai

3 Marwan, Kamus Hukum Dictionary of Law Complete Edition, Cetakan Kesatu, Surabaya: Reality Pubilser, 2009, hlm. 207.

4 Munir Fuady, Doktrin-doktrin Modern Dalam Corporate Law dan Eksistensinya Dalam Hukum Indonesia, Cetakan Kedua, Bandung: PT. Citra Aditya Bakti, 2010, hlm. 47.

5 Pasal 97 ayat (5) UU PT. 
pertanggungjawaban atas kerugian yang diderita oleh pihak perseroan atau pihak ketiga. Apabila direksi terbukti menyalahgunakan wewenang tersebut untuk kepentingan pribadi atau golongan yang mengakibatkan perseroan ataupun pihak ketiga mengalami kerugian, apakah direksi dapat dimintai tanggung jawab atas kerugian tersebut? Dari ulasan di atas Penulis ingin mengupas mengenai penerapan fiduciary duty dan piercing the corporate viel dalam UU PT.

\section{B. Tugas dan Wewenang Direksi Perseroan}

Tanggung jawab terbatas atau disebut juga limited liability atau limitatief aansprakelijheid adalah suatu kondisi di mana pemegang saham atau shareholder atau aandeelhouder dari suatu perseroan hanya bertanggung jawab sebatas pada sejumlah saham yang mereka miliki di perseroan tersebut. ${ }^{6}$ Tanggung jawab terbatas dilakukan sebagai pilihan investasi yang lebih menguntungkan. Limited liability ini tidak hanya mengikat pemegang saham saja tetapi juga pengurus perseroan yaitu direksi dan komisaris. Limited liability mengharuskan pemegang saham, direksi, dan komisaris dapat dengan pasti membedakan mana tindakan sebagai organ perseroan dan mana tindakannya sebagai perorangan. Semua tindakan pemegang saham, direksi, atau komisaris suatu perseroan telah ditentukan dalam peraturan perundang-undangan dan ADRT PT dan tidak diperbolehkan melakukan tindakan di luar kewenangan yang telah ditentukan tersebut.

Pada Pasal 1 angka 1 UU PT disebutkan bahwa perseroan adalah badan hukum. Hal ini memberikan arti bahwa perseroan dapat memiliki hak-hak dan kewajibankewajiban untuk melakukan suatu perbuatan seperti manusia, memiliki kekayaan sendiri, digugat dan menggugat di depan pengadilan. ${ }^{7}$ Suatu badan hukum dikatakan sebagai badan hukum apabila memenuhi syarat-sayarat sebagai berikut: ${ }^{8}$

1. Adanya harta kekayaan yang terpisah (hak-hak) dengan tujuan tertentu terpisah dengan kekayaan pribadi antara anggota atau sekutu atau pemegang saham dan badan hukum yang bersangkutan. Tegasnya ada pemisahan harta kekayaan antara kekayaan badan atau perusahaan dan kekayaan pribadi para anggota atau sekutu atau pemegang saham;

2. Ada kepentingan yang menjadi tujuan badan yang bersangkutan; dan

3. Adanya beberapa orang yang menjadi pengurus badan tersebut.

Perseroan mempunyai persoonlijkheid, ${ }^{9}$ yaitu suatu kemampuan untuk

6 Nindyo Pramono, "Perbandingan Perseroan di Beberapa Negara", Kegiatan Pelaksanaan dan Pengembangan Sistem Hukum Nasional Badan Pembinaan Hukum Nasional Kementerian Hukum dan Hak Asasi Manusia RI, 2012, hlm. 15.Dapat diunduh di www.bphn.go.id/data/documents/pk-2012-1.pdf.

7 Ridwan Khairandy, Perseroan Terbatas Doktrin, Peraturan Perundang-Undangan dan Yurisprudensi, Edisi Revisi, Yogyakarta: Total Media Yogyakarta, 2009, hlm. 5.

8 H. M. N. Purwosutjipto, Pengertian Pokok Hukum Dagang Indonesia, Jilid 2, dikutip dari Ibid, hlm. 11.

9 Chidir Ali, Badan Hukum, Bandung: Alumni, 1987, hlm. 24. 
menjadi subjek hukum dari hubungan hukum namun kecakapan yang dimiliki perseroan hanya terbatas dalam bidang harta kekayaan. Setiap keuntungan yang diperoleh oleh dari perbuatan hukum perseroan menjadi keuntungan pribadi perseroan. Apabila terjadi kerugian, hal tersebut menjadi beban perseroan tanpa melibatkan orang-orang yang ada dalam perseroan tersebut baik para pendiri atau organ-organ perseroan atau disebut separate legal entity.

Perseroan memiliki bentuk usaha mandiri (legal entity) dengan tangung jawab terbatas (limited liability). Kehendak dan kemauan yang dikehendaki perseroan dijalankan oleh alat-alat perlengkapannya atau organnya. Organ-organ tersebut mempunyai kewenangan dan tanggung jawab masing-masing sesuai yang telah diatur dalam peraturan perundang-undangan dan ADRT PT. Organ perseroan bertugas mewakili perseroan untuk dan atas nama perseroan.

Pada Pasal 1655 KUHPerdata disebutkan bahwa para pengurus badan hukum, bila tidak ditentukan lain dalam akta pendiriannya, dalam surat perjanjian, atau dalam reglemen, berkuasa untuk bertindak demi dan atas nama badan hukum itu, untuk mengikatkan badan hukum itu kepada pihak ketiga atau sebaliknya, dan untuk bertindak dalam sidang di pengadilan baik sebagai penggugat maupun sebagai tergugat. Badan hukum dalam hal ini adalah perseroan, dapat melakukan perbuatan hukum maupun hubungan hukum melalui organ pengurusnya yaitu organ-organ perseroan. Organ-organ perseroan bertugas mewakili perseroan sesuai dengan apa yang telah ditentukan dalam ADRT PT, dalam surat perjanjian dan dalam peraturan perundang-undangan. Masing-masing organ mempunyai tugas dan wewenang tersendiri sesuai aturan yang berlaku dalam perseroan tersebut.

Rapat Umum Pemegang Sahan (RUPS) adalah forum bagi pemegang saham memperoleh keterangan yang berkaitan dengan perseroan dari direksi dan/atau dewan komisaris, sepanjang berhubungan dengan mata acara rapat dan tidak bertentangan dengan kepentingan perseroan. ${ }^{10}$ Direksi merupakan penerima kuasa dari perseroan sesuai dengan kepentingannya untuk mencapai tujuan perseroan sebagaimana telah digariskan dalam ADRT PT, sehingga tidak diperkenankan melakukan sesuatu yang tidak atau bukan menjadi tugasnya. ${ }^{11}$ Komisaris mempunyai tugas utama mengawasi secara umum dan/atau khusus dan memberikan nasehat kepada direksi sesuai Pasal 1 angka 6 dan Pasal 108 ayat (1) UU PT. ${ }^{12}$ Organ perseroan mempunyai kewajiban mewakili perseroan untuk melakukan hubungan hukum dengan pihak ketiga dan untuk mewakili perseroan di dalam pengadilan baik sebagai pengggugat maupun sebagai tergugat. Organ-organ tersebut bertanggungjawab hanya sebatas kewenangannya.

\footnotetext{
10 Jono, Hukum Kepailitan, Cetakan ketiga, Edisi Kesatu, Jakarta: Sinar Grafika, 2008, hlm. 55.

11 Ahmad Yani, Seri Hukum Bisnis Perseroan Terbatas, Jakarta : Rajawali Pers, 1999, hlm. 97.

12 Jono, Hukum Kepailitan, Op.cit., hlm. 67.
} 
Setiap tugas dan tanggung jawab direksi dalam menjalankan perseroan harus tunduk kepada ketentuan atau peraturan yang mengatur mengenai perseroan sesuai dengan maksud dan tujuan didirikannya perseroan tersebut. ${ }^{13}$ Direksi dalam menjalankan pengurusan perseroan hanya untuk kepentingan perseroan dan sesuai dengan maksud dan tujuan perseroan sebagaimana yang diatur dalam Pasal 92 UU PT. ${ }^{14}$ Pada Pasal 2 UU PTditegaskan bahwa kegiatan perseroan harus sesuai dengan maksud dan tujuannya serta tidak bertentangan dengan peraturan perundang-undangan, ketertiban umum, dan atau kesusilaan. Selanjutnya, pada Pasal 18 UU PT ditentukan bahwa maksud dan tujuan tersebut harus dicantumkan dalam ADRT PT sesuai dengan ketentuan undang-undang. Penjelasan pada Pasal 18 UU PT disebutkan bahwa maksud dan tujuan tersebut merupakan usaha pokok perseroan, sedangkan kegiatan usaha merupakan kegiatan yang dijalankan oleh perseroan dalam rangka mencapai maksud dan tujuannya yang harus dirinci secara jelas dalam anggaran dasar, dan tidak boleh bertentangan dengannya. Perseroan tidak diperkenankan melakukan kegiatan yang tidak sejalan dengan maksud dan tujuan perseroan.

\section{Fiduciary Duty}

Direksi diberi dua fungsi dalam mengemban tugasnya, yaitu fungsi pengurusan (manajemen) dan fungsi perwakilan (representasi). ${ }^{15}$ Fungsi pengurusan seorang direksi dilakukan ketika direksi mengemban tugasnya sebagai seorang yang mengurus kegiatan perseroan sehari-hari. Fungsi perwakilan adalah tugas direksi mewakili perseroan baik di dalam maupun di luar pengadilan. Begitu besar dan luas kewenangan seorang direksi perseroan. Tugas yang diemban oleh direksi ini harus dijaga dan dilaksanakan sebaik-baiknya. Kewenangan yang diperoleh direksi dari para pemegang saham (shareholder) didasarkan atas dasar kepercayaan (fiduciary) untuk mengurus perseroan demi kepentingan perseroan, bukan demi kepentingan pemegang saham atau pihak tertentu. Fidusia (fiduciary) dalam bahasa latin dikenal sebagai fiduciarius yang bermakna kepercayaan. Secara teknis dapat dimaknai sebagai memegang suatu dalam kepercayaan untuk kepentingan orang. ${ }^{16}$

Direksi wajib beritikad baik (good faith) dan penuh tanggung jawab dalam setiap melakukan pengurusan perseroan. Hal itu dilakukan berdasarkan suatu standar dari kewajiban (standard of duty) yang paling tinggi sesuai dengan yang

13 Pasal 1 angka 5 UU PT.

14 Pasal 92 UU PT dijelaskan bahwa:

(1) Direksi menjalankan pengurusan perseroan untuk kepentingan perseroan dan sesuai dengan maksud dan tujuan perseroan;

(2) Direksi berwenang menjalankan pengurusan sebagaimana dimaksud pada ayat (1) sesuai dengan kebijakan yang dipandang tepat, dalam batas yang ditentukan dalam undang-undang ini dan/atau anggaran dasar.

15 Ridwan Khairandy, Perseroan Terbatas Doktrin, Op.cit.,hlm. 204.

16 Ibid. 
dinyatakan oleh hukum. Seseorang yang memegang peran sebagai suatu wakil (trustee) atau suatu peran yang disamakan dengan sesuatu yang berperan sebagai wakil, dalam hal ini peran tersebut didasarkan kepercayaan dan kerahasiaan (trust and confidence) yang dalam peran ini meliputi, ketelitian (scrupulous), itikad baik (good faith), dan keterusterangan (candor). Fiduciary ini termasuk hubungan seperti pengurus atau pengelola, pengawas, wakil atau wali, dan pelindung (guardian) yang sering disebut dengan duty. ${ }^{17}$

Hubungan antara direksi dan perseroan tidak semata-mata hanya hubungan pekerjaan saja tetapi juga hubungan fidusia (fiducia position). Perseroan tidak dapat bertindak sendiri dan sangat tergantung kepada pengurusannya. Ketergantungan ini mengharuskan perseroan untuk mempercayai pengurus yang kemudian melahirkan hubungan fidusia dan lebih dikenal dengan fiduciary duty. Pengurus harus menjalankan kepengurusan dan kewenangannya semata-mata hanya untuk kepentingan perseroan. Fiduciary duty adalah tugas yang dijalankan oleh direksi dengan penuh tanggung jawab untuk kepentingan (benefit) orang atau pihak lain (perseroan). ${ }^{18}$ Apabila terjadi masalah manakala suatu perseroan beroperasi tidak layak sehingga menimbulkan kerugian pihak ketiga atau pemegang saham, dalam hal ini direksi bertanggung jawab sebagai pihak eksekutif berdasarkan doktrin fiduciaryduty. ${ }^{19}$

Istilah fiduciary duty berasal dari kata duty yang berarti tugas dan fiduciary (bahasa Inggris) berasal dari bahasa Latin fiduciarus dengan akar kata fiducia yang berarti kepercayaan (trust) atau fidere yang berarti mempercayai (to trust). Jadi, istilah fiduciary diartikan sebagai memegang sesuatu dalam kepercayaan atau seseorang yang memegang sesuatu dalam kepercayaan untuk kepentingan orang lain. Bahasa Inggris menyebutkan orang yang memegang kepercayaan dari orang lain disebut trustee dan pihak yang dipegang kepentingannya disebut beneficiary. Pada istilah bahasa Indonesia, pemegang kepercayaan disebut sebagai pemegang amanah. ${ }^{20}$

Pada Pasal 97 ayat (2) dan (3) UU PT ditentukan bahwa kepengurusan yang dipercayakan kepada direksi harus dilaksanakan dengan itikad baik dan penuh tanggung jawab penuh sampai kepada harta pribadi direksi apabila direksi terbukti lalai dalam menjalankan tugasnya. ${ }^{21}$ Fiduciary duty yang telah diberikan kepada

17 Bismar Nasution, “Tanggung Jawab Direksi dalam Pengelolaan Perseroan”, http://bismar.wordpress.com/, diakses 13 Mei 2012.

Prof. Dr. Bismar Nasution, S.H.,M.H. adalah Guru Besar Universitas Sumatra Utara dengan bidang keahlian Hukum Ekonomi.

18 Ridwan Khairandy, Perseroan Terbatas, Op.cit., hlm. 210.

19 Munir Fuady, Doktrin-doktrin Modern Dalam Corporate Law, Op.cit., hlm. 25.

$20 \mathrm{lbid}, \mathrm{hlm}$. 30-31.

${ }^{21}$ Milman dan Durrant, ada situasi dimana seorang direksi perseroan mungkin dapat dituntut untuk membayar kerugian karena telah melakukan perbuatan melanggar hukum (toruous behaviour). Kemungkinan yang pertama 
direksi suatu perseroan menuntutnya untuk memiliki standar integritas dan loyalitas yang tinggi, terampil, serta bertindak untuk kepentingan perseroan secara bona fides. ${ }^{22}$ Pada Pasal 97 ayat (6) UU PT ditentukan bahwa apabila anggota direksi yang bersangkutan bersalah atau lalai melaksanakan tugasnya dengan baik sehingga perseroan dirugikan, maka ia bertanggung jawab penuh secara pribadi dan pemegang saham dapat mengajukan gugatan ke pengadilan negeri. Fiduciary duty dijalankan oleh direksi dengan cara: ${ }^{23}$

a. Dilakukan dengan itikad baik (bona fides);

b. Dilakukan dengan proper purpose;

c. Dilakukan dengan kebebasan yang bertanggung jawab (unfettered discretion); dan

d. Tidak memiliki benturan kepentingan (conflict of duty and interest).

Tanggung jawab direksi tidak hanya terbatas pada ketidakjujuran yang disengaja tetapi juga tanggung jawab dalam tindakan mismanagement, kelalaian, kegagalan atau tidak melakukan sesuatu yang penting bagi perseroan.ltikad baik direksi dapat dilihat ketika direksi benar-benar mementingkan kepentingan perseroan, shareholder, dan stakeholder. Proper purpose (tujuan yang benar) dijalankan dengan menaati ADRT PT dan peraturan perundang-undangan. Menurut M. Yahya Harahap, ada beberapa aspek pengurusan yang wajib dilakukan dengan itikad baik, yaitu: ${ }^{24}$

a. Wajib dipercaya (fiduciary duty), yakni selama dapat dipercaya (must always bonafide) dan selamanya harus jujur (must always honest);

b. Wajib melaksananakan pengurusan untuk tujuan yang wajar atau layak (duty to act for properpurpose);

c. Wajib menaati peraturan perundang-undangan (statutory duty or duty obedience);

d. Wajib loyal terhadap perseroan (loyalty duty), tidak menggunkan dana dan aset

adalah tuntutan karena kelalaian yang dilakukan oleh kreditor dari perseroan yang mengalami kesulitan ekonomi. Jenis pertanggungjawaban kedua dapat timbul apabila perseroan melakukan perbuatan melawan hukum. Hal tersebut juga dianut oleh Indonesia yang keudian dituangkan dalam Pasal 97 ayat (1), (2), dan (3) UU PT disebutkan bahwa:

(1) Direksi bertanggung jawab atas pengurusan perseroan sebagaimana dimaksud dalam Pasal 92 ayat (1).

(2) Pengurusan sebagaimana dimaksud pada ayat (1), wajib dilaksanakan setiap anggota direksi dengan itikad baik dan penuh tanggung jawab.

(3) Setiap anggota direksi bertanggung jawab penuh secara pribadi atas kerugian perseroan apabila yang bersangkutan bersalah atau lalai menjalankan tugasnya sesuai dengan ketentuan sebagaimana dimaksud pada ayat (2).

Sutan Remi Syahdeni, "Tanggung Jawab Pribdai Direksi dan Komisaris,"Jurnal Hukum Bisnis, Volume 14, No. 7, 2001.

22 Ridwan Khairandy, Perseroan Terbatas Doktrin, Op.cit., hlm. 208.

23 Ibid, hlm.209.

24 M. Yahya Harahap, Hukum Perseroan, Op.cit., hlm. 383 
perseroan untuk kepentingan pribadi, wajib merahasiakan segala informasi (confidential duty of information) perseroan; dan

e. Wajib menghindari kepentingan pribadi dengan kepentingan perseroan (must avoid conflict of interest).

Direksi wajib melaksanakan pengurusan dengan penuh tangung jawab, yang meliputiaspek: ${ }^{25}$

a. Wajib seksama dan hati-hati melakukan pengurusan (the duty of the due care), yakni kehati-hatian yang biasa dilakukan orang (ordinary prudent person) dalam kondisi yang wajar atau disebut dengan kehati-hatian yang wajar (reasonably care);

b. Wajib melaksanakan pengurusan secara tekun (duty to be diligent), yakni terus menerus secara wajar menumpahkan perhatian atas kejadian yang menimpa perseroan; dan

c. Ketekunan dan keuletan wajib disertai kecakapan dan keahlian (duty to display skill) sesuai dengan ilmu pengetahuan dan pengetahuan yang dimilikinya.

Seorang direksi tidak dapat dimintai pertanggungjawaban secara pribadi atas tindakan yang telah dilakukannya dalam kedudukannya sebagai direksi, apabila ia meyakini bahwa tindakan tersebut merupakan tindakan yang terbaik bagi perseroan dan dilakukan secara jujur, beritikad baik, dan tidak bertentangan dengan hukum yang berlaku. Direksi tidak akan dimintai pertanggungjawaban walaupun salah dalam mengambil keputusan (mere errors of judgement) ketika direksi beritikad baik dan penuh kehati-hatian dalam menjalankan tugasnya. Hal ini akan membantu direksi karena hakim tidak diperbolehkan melakukan penilaian bisnis yang berbentuk second guess terhadap keputusan bisnis yang diambil oleh direksi sesuai dengan teori keputusan bisnis (business judgement rule). ${ }^{26}$ Setiap keputusan direksi yang diambil dilindungi oleh business judgement rule, namun direksi tetap harus beritikad baik, berhati-hati, dan penuh loyalitas dalam menjalankan kepengurusan perseroan.

Negara-negara Common Law seperti Amerika Serikat mempunyai standar yang jelas untuk meminta pertanggungjawaban direksi atas tindakan yang diambilnya, yaitu didasarkan pada standar duty of loyality dan duty of care. ${ }^{27}$ Adapun pengertiannya adalah:

a. Duty of loyality; dalam menduduki posisi sebagai anggota direksi, tidak menggunakan dana perseroan untuk dirinya atau untuk tujuan pribadinya dan secara loyal, wajib merahasiakan segala informasi (confidential duty of information) perseroan yang meliputi: ${ }^{28}$ setiap rahasia perusahaan yang

\footnotetext{
25 Ibid.

${ }^{26}$ Munir Fuady, Doktrin-Doktrin Modern dalam Corporate Law, Op.cit.,hlm. 48.

27 Bismar Nasution, Loc. cit.

${ }^{28}$ M. Yahya Harahap, Hukum Perseroan Terbatas, Op.cit., hlm. 376.
} 
berharga bagi kepentingan perseroan, segala fomula rahasia (secret formula), desain produksi, strategi pemasaran, dan daftar konsumen yang harus dirahasiakan;

b. Duty of care (prudential duty); anggota direksi tidak boleh sembrono (carelessly) dan lalai (negligence) melaksanakan pengurusan menurut hukum yang berpatokan pada standar kehati-hatian yang lazim digunkan oleh orang biasa (the kind of care that an ordinary prudent person). ${ }^{29}$

Posisi direksi sebagai sebuah trustee dalam perseroan mewajibkan direksi untuk bertanggung jawab kepada perusahaan secara keseluruhan bukan kepada pemegang saham baik secara individu maupun kelompok. Direksi tidak boleh bertindak ceroboh dalam melakukan tugasnya (duty of care). Selain itu dalam melakukan tugasnya tersebut seorang direksi tidak boleh mengambil keuntungan untuk dirinya sendiri atas perusahaan (duty of loyality). ${ }^{30}$ Pelanggaran terhadap kedua prinsip tersebut dalam kaitannya dengan fiduciary duty dapat menyebabkan direksi dimintai pertanggungjawaban hukum secara pribadi baik oleh pemegang saham atau pihak ketiga.Pembenanan pertanggungjawaban kepada direksi, terlebih dahulu harus dibuktikan adanya pelanggaran kewenangan yang dimilikinya. Itikad baik yang dimaksud dalam fiduciary duty tidak dijalankan oleh direksi sehingga dapat dengan jelas bahwa direksi tersebut melanggar fiduciary duty.

Menurut identification theory dalam wacana Common Law di atas, kesalahan yang dilakukan oleh anggota direksi atau organ perseroan lainnya dapat dibebankan pada korporasi jika memenuhi syarat sebagai berikut: ${ }^{31}$

a. Tindakan yang dilakukan oleh mereka berada dalam batas tugas atau instruksi yang diberikan pada mereka;

b. Bukan merupakan penipuan yang dilakukan untuk perusahaan;

1) Dimaksudkan untuk menghasilkan atau mendatangkan keuntungan bagi korporasi; dan

2) Jika salah satu syarat ini tidak dipenuhi, maka kesalahan tersebut tidak dapat dipikul oleh korporasi, namun harus dipikul secara pribadi oleh organ korporasi yang melakukan tindakan tersebut.

Pada Pasal 97 ayat (2) UU PT diwajibkan setiap anggota direksi untuk beritikad baik dan penuh tangggung jawab dalam melaksanakan setiap tugas. ${ }^{32}$ Pasal inilah yang memberikan dasar pemberlakuan fiduciary duty oleh direksi di Indonesia.

\footnotetext{
${ }^{29} \mathrm{Ibid}, \mathrm{hlm} .379$.

30 Joel Seligman, Corporations Cases and Materials, Boston New York Toronto London: Little Brown and Company, 1995, dalam Bismar Nasution, Loc.cit.

31 lbid.

32 Pada Pasal 97 ayat (2) UU PT menyebutkan "pengurusan sebagaimana dimaksud pada ayat (1), wajib dilaksanakan setiap anggota direksi dengan itikad baik dan penuh tanggung jawab."
} 
Fiduciary duty ini berlaku bagi kepentingan perseroan. ${ }^{33}$ Direksi berkewajiban untuk mengelola dan mengurus kepentingan perseroan secara keseluruhan bukan kepentingan pemegang saham baik secara individu maupun kelompok ataupun pihak ketiga. Hal ini sesuai dengan posisi seorang direksi sebagai sebuah trustee dalam perusahaan. Pelanggaran terhadap prinsip tersebut menyebabkan direksi untuk dimintai pertanggungjawaban hukumnya secara pribadi terhadap perbuatan yang dilakukannya baik kepada para pemegang saham maupun kepada pihak lainnya.

Pemberlakuan prinsip fiduciary duty kepada direksi perseroan mengharuskan direksi dalam menjalankan tugasnya memenuhi kriteria-kriteria berikut: ${ }^{34}$

a. Harus selalu beritikad baik;

b. Harus jujur kepada perseroan;

c. Memiliki skill yang wajar seperti yang dimiliki secara wajar oleh umumnya orang yang memiliki pengetahuan dan pengalaman yang sama dengannya;

d. Memedulikan perseroan;

e. Loyalitas yang tinggi; dan

f. Mengambil keputusan yang reasonable secara bisnis sungguhpun mungkin bukan keputusan yang optimal.

Pedoman dasar bagi direksi dalam menjalankan fiduciary duty terhadap perseroan yang dipimpinnya ialah: ${ }^{35}$

a. Fiduciary duty merupakan unsur wajib (mandatory element) dalam hukum perseroan;

b. Dalam menjalankan tugasnya, seorang direksi tidak hanya harus memenuhi unsur itikad baik, tetap juga harus memenuhi unsur tujuan yang layak (proper purpose);

c. Pada prinsipnya direksi dibebani prinsip fiduciary duty terhadap perseroan, bukan terhadap pemegang saham, arena itu hanya perusahaanlah yang dapat memaksakan direksi untuk melaksanakan tuga fiduciary duty tersebut;

d. Dalam menjalankan fungsinya sebagai direksi, secara umum ia juga harus memerhatikan kepentingan stakeholders, seperti pihak pemegang saham dan buruh perusahaaan;

e. Sungguhpun menyandang tugas sebagai direksi, ia tetap bebas dalam memberikan suara dan pendapat sesuai dengan keyakinan dan kepentingannya dalam setiap rapat yang dihadiri;

\footnotetext{
33 Ketentuan ini dapat dilihat pada Pasal 97 ayat (1) yaitu, "(1) Direksi bertanggung jawab atas pengurusan Perseroan sebagaimana dimaksud dalam Pasal 92 ayat (1)". Pada Pasal 1 butir 5 disebutkan bahwa, "Direksi adalah organ perseroan yang berwenang dan bertanggungjawab penuh atas pengurusan perseroan untuk kepentingan perseroan, sesuai dengan maksud dan tujuan perseroan serta mewakili perseroan, baik di dalam maupun di luar pengadilan sesuai dengan ketentuan anggaran dasar".

${ }^{34}$ Munir Fuady, Doktrin-doktrin Modern Dalam Corprorate Law, Op.cit., hlm. 54.

35 Ibid, hlm. 59.
} 
f. Direksi tetap bebas dalam mengambil keputusan sesuai pertimbangan bisnis dan sense of business yang dimilikinya. Bahkan, pihak pengadilan tidak boleh ikut campur mempertimbangkan sense of business dari pihak direksi; dan

g. Dalam hal-hal di mana terdapat conflic of interest, seorang direksi dilarang atau setidak-tidaknya dibatasi atau diawasi dalam menjalankan tugasnya. Pengawasan tersebut misalnya dengan memberlakukan perinsip keterbukaan (disclosure) terhadap setiap transaksi yang ada conflic of interest.

Setiap tindakan dari direksi selalu mendapat pengawasan dari komisaris perseroan. Komisaris adalah organ perseroan yang bertugas melakukan pengawasan secara umum dan/atau khusus sesuai dengan anggaran dasar serta memberi nasihat kepada direksi. ${ }^{36}$ Sistem hukum perseroan di negara AngloAmerika yang tidak mengenal komisaris tetapi mereka mengenal board of directors, berbeda dengan sistem hukum perseroan di Indonesia yang mempunyai komisaris. Komisaris dalam hukum perseroan di Indonesia mirip dengan jabatan komisaris, yang dikenal dalam hukum perseroan Belanda. ${ }^{37}$ Board of directors juga dikenal dalam Common Law. Pada umumnya dalam sistem Common Law, board of directors dibagi menjadi dua bagian yaitu: ${ }^{38}$

a. Chief Executive Officer (CEO), yang berfungsi dan bertanggung jawab melaksanakan pengurusan perseroan sehari-hari; dan

b. Chairman, berkedudukan sebagai direksi non-eksekutif (non-executive director).

Non-executive director sama seperti CEO karena memiliki keterampilan dan pengalaman dalam kedireksian. Perseroan besar atau perseroan publik harus mempunyai non-executive director. Non-executive director bersikap independen dan objektif dalam mengambil keputusan dan pengawasan terhadap perseroan, terutama dalam penyelesian benturan kepentingan antara executive directors dengan kepentingan lain. ${ }^{39}$

Pada Australian the Corporation Act 2001 dalam section 181-183 diatur juga mengenai direksi yang harus bertindak dengan itikad baik dan tidak menyalahgunakan posisi dan informasi yang dia dapat karena kedudukannya sebagai direksi (company directors must act in good faight in the best interest of proper purpose not misuses one's position within the company and not misuse information obtained because of their position as a director or officer of the company). ${ }^{40}$ Rudhi Prasetya menyatakan bahwa termasuk sebagai tugas direksi

\footnotetext{
${ }^{36}$ Pasal 1 angka 6UU PT.

37 Bismar Nasution, Loc.cit.

38 Shinta Ikayani Kusumawardani, "Pengaturan Kewenangan, dan Tanggung Jawab Direksi dalam Perseroan Terbatas (Studi Perbandingan Indonesia dan Australia)", Jurnal Magister Hukum Udayana, Vol 2, No 1 Tahun 2013, hlm. 5.

39 Ibid.

40 Ibid.
} 
dalam perbuatan dan kejadian sehari-hari, menurut anggaran dasar: ${ }^{41}$

a. menandatangani saham-saham yang dikeluarkan, bersama komisaris;

b. menyusun laporan neraca untung rugi perseroan pada akhir tahun, sebagai pertanggungjawaban direksi, dengan menyampaikannya dan meminta untuk disahkan oleh RUPS;

c. melakukan pemanggilan RUPS dan memimpin RUPS (khusus untuk PT terbuka RUPS dipimpin oleh komisaris).

Tugas direksi dilihat dari substansinya dapat dibedakan menjadi empat kategori, yakni: ${ }^{42}$

a. tanggung jawab berdasarkan prinsip fiduciary duties dan duty to skill and care;

b. tanggung jawab berdasarkan doktrin manajemen ke dalam (indoor management rule);

c. tanggung jawab berdasarkan prinsip ultra vires; dan

d. tanggung jawab berdasarkan prinsip piercieng the corporate veil.

\section{Piercing the Corporate Veil}

Beberapa pakar dan ilmuwan hukum merumuskan kedudukan direksi dalam perseroan sebagai gabungan dari dua macam persetujuan/perjanjian, yaitu perjanjian pemberian kuasa di satu sisi dan perjanjian kerja/perburuhan di sisi lain. ${ }^{43}$ Berdasarkan perjanjian tersebut pelaksanaannya harus di tafsirkan berdasarkan ketentuan dalam Pasal 1601c KUHPerdata, yang memberatkan pelaksanaan perjanjian-perjanjian tersebut sebagai suatu perjanjian perburuhan. ${ }^{44}$ Rumusan kedudukan direksi dalam dua hubungan hukum seperti yang telah disebutkan di atas bukan masalah, sepanjang kedua hubungan hukum tersebut dapat diterapkan secara konsisten dan sejalan.

41 M. Hadi Subhan, Hukum Kepailitan, Prinsip, Norma dan Praktik di Peradilan, EdisiPertama, Cetakan ke-1, Jakarta: Prenada Media Group, 2008, hlm. 227.

42 Ibid.

${ }^{43}$ Freddy Harris \& Teddy Anggoro, Hukum Perseroan Terbatas Kewajiban Pemberitahuan oleh Direksi, Bogor: PT Ghalia Indonesia, 2010, hlm. 37-38.

44 Pasal 1601 c KUHPerdata menjelaskan bahwa, “Jika suatu persetujuan mengandung sifat-sifat suatu perjanjian kerja dan persetujuan lain, maka baik ketentuan-ketentuan mengenai perjanjian kerja maupun ketentuanketentuan mengenai persetujuan lain yang sifat-sifatnya terkandung di dalamnya, keduanya berlaku; jika ada pertentangan antara kedua jenis ketentuan tersebut, maka yang berlaku adalah ketentuan-ketentuan mengenai perjanjian kerja. Jika pemborongan kerja diikuti dengan beberapa persetujuan sejenis itu, meskipun tiap kali dengan suatu selang waktu, atau jika pada waktu persetujuan dibuat, ternyata maksud kedua belah pihak membuat beberapa persetujuan secara demikian ialah supaya pemborongan-pemborongan itu dapat dipandang sebagai suatu perjanjian kerja, maka peraturan-peraturan mengenai perjanjian kerja harus berlaku bagi semua persetujuan ini, baik bagi semua persetujuan itu secara serempak maupun bagi masing-masing persetujuan secara sendiri-sendiri. Kecuali ketentuan-ketentuan dalam Bagian 6 pada bab ini. Akan tetapi bila dalam hal demikian persetujuan yang pertama hanya diadakan untuk percobaan saja, maka persetujuan demikian harus dianggap mengandung sifat pemborongan kerja dan segala ketentuan dalam Bab 6 itu berlaku baginya". 
Direksi sebagai penerima kuasa dari perseroan untuk menjalankan perseroan sesuai dengan kepentingannya untuk mencapai tujuan perseroan sebagaimana telah digariskan dalam ADRT PT. Direksi diperlakukan sebagai karyawan perseroan, namun dalam hubungan atasan dan bawahan dalam perjanjian perburuhan, direksi tidak diperkenankan untuk melakukan sesuatu yang bukan tugasnya.

Perseroan sebagai badan hukum membawa konsekuensi terhadap tanggung jawab terbatas pemegang saham, komisaris, dan direksi. Sejak disahkan Akta Pendirian Perseroan oleh Menteri Kehakiman dan HAM, status perseroan berubah menjadi badan hukum yang membawa konsekuensi terbatasnya tanggung jawab. Pemegang saham perseroan tidak bertanggung jawab secara pribadi atas perikatan yang dibuat atas nama perseroan dan tidak bertanggung jawab atas kerugian perseroan yang melebihi nilai saham yang telah diambilnya. ${ }^{45}$ Pemegang saham dalam kaitannya dengan tanggung jawab terhadap perseroan hanya terbatas pada nilai nominal semua saham yang dimilikinya. ${ }^{46}$

Perseroan sebagai badan hukum membawa konsekuensi terhadap tanggung jawab terbatas pemegang saham, komisaris, dan direksi. Pada perkembangannya, prinsip limited liability tidak berlaku mutlak sejak dikenal doktrin piercing the corporate veil, yang dalam hal tertentu tertutup kemungkinan dihapusnya tanggung jawab terbatas pemegang saham, komisaris, dan direksi perseroan. Istilah piercing the corporate veil kadang-kadang disebut juga dengan istilah "lifting the corporate veil" atau "going behind the corporate veil". Secara harafiah, istilah "piercing the corporate veil" berarti mengoyak tirai perusahaan. Pada ilmu hukum perusahaan, istilah piercing the corporate law merupakan suatu doktrin atau teori yang diartikan sebagai suatu proses untuk membebani tanggung jawab ke pundak orang atau perusahaan lain, atas perbuatan hukum yang dilakukan oleh suatu perusahaan pelaku (badan hukum), tanpa melihat kepada fakta bahwa perbuatan tersebut sebenarnya dilakukan oleh pelaku perseroan tersebut. ${ }^{47}$ Terbatasnya tanggung jawab tersebut tidak hanya berlaku bagi pemegang saham tetapi juga berlaku bagi organ perseroan yang lainnya baik direksi maupun komisaris. Pada hal tertentu, tanggung jawab terbatas dapat dihapuskan dan dimungkinkan menembus harta pribadi pemegang saham. Hal inilah yang disebut sebagai piercing the corporate veil. ${ }^{48}$

45 Gunawan Widjaja, Tanggung Jawab Direksi atas Kepailitan, Cetakan Kedua, Jakarta: PT Raja Grafindo Persada, 2004, hIm. 19.

46 Ridwan Khairandy, "Perseroan Terbatas Sebagai Badan Hukum”, Jurnal Hukum Bisnis, Volume 26, Nomor 3, 2007, hlm. 5.

47 Munir Fuady, Doktrin-doktrin modern, Op.cit., hlm. 7.

48 Hapusnya tanggung jawab terbatas antara lain disebabkan perseroan belum disahkan menjadi badan hukum oleh penguasa/pemerintah, pemegang saham beritikad buruk memanfaatkan perseroanaan untuk kepentingan pribadi, terlibat perbuatan melanggar hukum yang dilakukan perseroan, menggunakan kekayaan perseroan sehingga perseroan tidak memiliki cukup kekayaan untuk membayar utang. 
Setiap perseroan harus memiliki maksud dan tujuan serta kegiatan usaha yang jelas dan tegas yang merupakan landasan bagi direksi mengadakan kontrak dan transaksi bisnis dan menentukan batasan kewenangan direksi melakukan kegiatan usaha.Seluruh kewenangan dan tugas direksi telah ditentukan dalam ADRT PT. Peraturan perundang-undangan tidak boleh bertentangan dengan peraturan yang berlaku dan ketertiban umum. Apabila direksi dengan sengaja berbuat melampaui kewenangannya, maka dapat dikenakan ultra vires. Direksi yang dengan sengaja melanggar batas kewenangan tersebut dapat disebut telah melakukan tindakan ultra vires. Setiap tindakan ultra vires batal demi hukum karena tidak mempunyai landasan yuridis. Tindakan direksi tersebut tidak mempunyai kewenangan baik dari ADRT PT ataupun peraturan perundang-undangan yang berlaku. Tuntutan keadilan menyebabkan beberapa perbuatan yang digolongkan dalam ultra vires tidak dibatalkan, yaitu: ${ }^{49}$

a. Restitusi (pengembalian) aset yang sudah dialihkan dengan transaksi yang ultra vires tidak mungkin dikembalikan lagi;

b. Perseroan telah diberi ganti rugi terhadap kerugian yang terjadi karena transaksi ultra vires tersebut;

c. Pembatalan transaksi akan merugikan hak yang didapat tidak secara gratis dari pihak ketiga yang beritikad baik di luar kontrak;

d. Transaksi yang mengandung ultra vires tersebut telah diratifikasi oleh RUPS atau oleh resolusi dari pemegang saham.

Akibat dari tidakan ultra vires adalah pihak yang dirugikan dapat meminta ganti rugi kepada direksi yang bersangkutan. Hal ini akan menjadi tanggung jawab tidak terbatas menjadi terkoyak karena kesalahan direksi. Apabila direksi terbukti melakukan kesalahan secara pribadi yang menyebabkan timbulnya kerugian bagi perseroan, maka direksi bertanggung jawab penuh secara pribadi untuk mengganti segala kerugian yang ditimbulkan terhadap perseroan. Direksi yang secara sengaja dengan itikad buruk melakukan perbuatan melawan hukum dengan menggunakan harta kekayaan perseroan untuk kepentingan pribadinya sehingga menyebabkan timbulnya kerugian bagi perseroan dapat dijerat dengan piercing the corporate veil. ${ }^{50}$ Piercing the corporate veil diberlakukan pada direksi apabila direksi terbukti melakukan kesalahan secara pribadi yang menyebabkan timbulnya kerugian

\footnotetext{
49 Ibid., hlm. 124.

50 Pada UU PT diakui teori peircing the corporate veil dengan membebankan tanggung jawab kepada pihak-pihak sebagai berikut:

a. Beban tanggung jawab dipindahkan ke pihak pemegang saham. Ketentuan tersebut terdapat dalam Pasal 3 ayat (2) beserta penjelasannya.

b. Beban tanggung jawab dipindahkan ke pihak direksi. Ketentuan tersebut terdapat dalam Pasal 1 angka 5, Pasal 69 ayat (3), Pasal 97 ayat (3), Pasal 104 ayat (2).

c. Beban tanggung jawab dipindahkan ke pihak komisaris. Ketentuan tersebut terdapat dalam Pasal 114 ayat (2), Pasal 108 ayat (1), Pasal 115 ayat (1).
} 
perseroan. Tanggung jawab direksi berubah menjadi tanggung jawab tidak terbatas dan direksi bertanggung jawab penuh secara pribadi untuk mengganti segala kerugian yang ditimbulkan terhadap perseroan.

Nindyo Promono memberikan kelanjutan dari piercing the corporate veil dikenal dengan nama alter ego yaitu, jika seorang pemegang saham suatu perseroan menguasai mayoritas saham pada perseroan tertentu, kemudian perseroan tersebut dipakai untuk tujuan-tujuan tertentu oleh pemegang saham tersebut melalui kekuasaan mayoritasnya sebagai pemegang saham. Maka, secara tidak langsung perseroan digunakan sebagai alat oleh pemegang saham untuk tujuan tertentu dari pemegang saham, yakni untuk mencapai keuntungan pribadi bahkan tidak tertutup kemungkinan dapat merugikan pihak ketiga. Kedua doktrin ini memberikan perlindungan hukum bagi pihak ketiga apabila organ perseroan bertindak di luar wewenangnya untuk kepentingan pribadi ataupun golongan sehinga merugikan pihak ketiga.

Piercing the corporate veil tidak dengan mudah diterapkan oleh pengadilan karena limited liability yang dimiliki perseroan amat kuat dan tidak tergoyahkan begiu saja. Penerapan percing the corporate veil oleh pengadilan dilakukan dengan memperhatikan substansi atau kenyataan praktis pada bentuk formal dari perseroan tersebut. ${ }^{51}$ Apabila terdapat kemungkinan perseroan disalahgunakan atau dijadikan selubung oleh pemegang saham atau direksi atau komisaris, maka pengadilan akan menyingkap tabir perseroan tersebut dan membuka maksud terselubung organ perseroan tersebut.

Sebagaimanana menurut Philiip Lepton, Pengadilan Australia secara umum tabu untuk membuka cadar perseroan tertabatas. ${ }^{52}$ Penerobosan cadar perseroan di Australia sangat jarang terjadi. Penulis buku Understanding Company Law menyebutkan beberapa alasan yang menyebabkan pengadilan di Australia menerobos cadar perseroan diantara adalah: ${ }^{53}$

a. where a company is used as vehicle for fraud;

b. if a company has been used so as to avoid a legal duty;

c. if the incorporation of a company can be seen to be a sham 77 or the company is mere "puppet" of its controller;

d. if a company knowingly participates in a director's breach of her or his fiduciary duties.

Penerobosan tanggung jawab terbatas pada perseroan di Australia dapat dilakukan antara lain dalam hal perseroan dipergunakan sebagai alat untuk

${ }^{51}$ Chatamarrasjid Ais, Penerobosan Cadar Perseroan dan Soal-soal Aktual Hukum Perusahaan, Jakarta: Citra Aditya Bakti, 2004, hlm. 14.

52 Phillip and Lipton dan Abe Herzberg, Understanding Company Law, Perth: The Law Book Company Limited, 1993, hlm. 31, dalam Shinta Ikayani Kusumawardani, Loc.cit.

53 lbid. 
melakukan penipuaan, penghindaran suatu kewajiban hukum, sebagai topeng semata oleh pengendali, atau jika direksi melanggar kewajiban fiduciary. ${ }^{54}$ Doktrin ultra vires dimaksudkan untuk melindungi para investor atau pemegang saham dari tindakan direksi yang merugikan perseroan. Tindakan ultra vires adalah tidak sah (unlawful) dan batal demi hukum sehingga RUPS tidak dapat mengesahkannya. Kontrak tersebut tidak mengikat perseroan dan perseroan tidak wajib melaksanakannya.

\section{E. Tanggung Jawab Direksi Perseroan Terbatas}

Direksi sebagai organ yang bertugas dan bertanggung jawab melaksanakan pengurusan perusahaan sangat berpotensi melakukan pelanggaran atau penyimpangan tugas dan kewajiban yang dibebankan kepada direksi. Direksi yang secara sengaja dengan itikad buruk melakukan perbuatan melawan hukum dengan menggunakan harta kekayaan perseroan untuk kepentingan pribadinya, sehingga menyebabkan timbulnya kerugian bagi perseroan, maka diterapkan asas piercing the corporate veil yaitu pertanggungjawaban penuh secara pribadi untuk mengganti segala kerugian yang ditimbulkan terhadap perseroan jika direksi terbukti melakukan kesalahan secara pribadi yang menyebabkan timbulnya kerugian bagi perseroan. Pengadilan akan mengesampingkan status badan hukum perseroan tersebut dan membebankan tanggung jawab kepada direksi dengan mengabaikan prinsip tanggung jawab terbatas. Apabila direksi terbukti melakukan kesalahan secara pribadi yang menyebabkan timbulnya kerugian bagi perseroan, maka tidak ada lagi ruang bagi direksi sebagai pengurus perseroan untuk melakukan perbuatan yang dapat menimbulkan kerugian bagi perseroan, pemegang saham, ataupun pihak ketiga.

Pada tindakan direksi yang menyebabkan kerugian bagi perseroan dan berakhir kepada pailitnya perseroan, direksi wajib bertanggung jawab secara renteng atas kerugian tersebut. ${ }^{55}$ Ini merupakan akibat dari kegagalan direksi yang dipercaya untuk mengurus perseroan. Apabila kekayaan perseroan tidak cukup untuk menutup kewajiban perseroan, maka harta direksi yang bersangkutan akan digunakan untuk menutup kewajiban tersebut. Sifat pertanggungjawaban renteng dan pertanggungjawaban pribadi direksi menjadi sangat relevan dalam hal direksi melakukan penyimpangan atas kuasa dan perintah perseroan untuk kepentingan perseroan.

Hal itu secara tegas diakui Pasal 92 ayat (2) UU PT dan penjelasannya. Direksi berwenang menjalankan kepengurusan perseroan dengan menerapkan kebijakan yang dianggap tepat, yaitu kebijakan yang didasarkan pada keahlian, peluang yang

\footnotetext{
54 Ibid.

55 Gunawan Widjaja, Tanggung Jawab, Op.cit., hlm. 145.
} 
tersedia, dan kelaziman dalam dunia usaha yang sejenis. ${ }^{56}$ Direksi harus selalu bertindak berdasarkan itikad baik dengan mengacu pada informasi yang cukup dan diolah secara cakap berdasarkan kemampuannya. ${ }^{57}$

Apabila direksi terbukti melakukan kesalahan secara pribadi yang menyebabkan timbulnya kerugian bagi perseroan, maka tanggung jawab direksi berubah menjadi tanggung jawab tidak terbatas, sehingga direksi bertanggung jawab penuh secara pribadi untuk mengganti segala kerugian yang ditimbulkan terhadap perseroan. Pengadilan akan mengesampingkan status badan hukum dari perseroan tersebut dan membebankan tanggung jawab kepada direksi dengan mengabaikan prinsip tanggung jawab terbatas apabila direksi terbukti melakukan kesalahan secara pribadi yang menyebabkan timbulnya kerugian bagi perseroan. Hal tersebut membuat tidak ada lagi ruang bagi direksi sebagai pengurus perseroan untuk melakukan perbuatan yang dapat menimbulkan kerugian bagi perseroan.

Apabila di dalam pelaksanaan dan/atau berjalannya perseroan direksi melakukan kesalahan pelanggaran atas tugas-tugasnya, maka sebagaimana pada Pasal 97 ayat (2) dan (3) UU PT dapat dikenakan sanksi sebagai berikut:

"(2) Pengurusan sebagaimana dimaksud pada ayat (1), wajib dilaksanakan setiap anggota direksi dengan itikad baik dan penuh tanggung jawab;

(3) Setiap anggota direksi bertanggung jawab penuh secara pribadi atas kerugian perseroan apabila yang bersangkutan bersalah atau lalai menjalankan tugasnya sesuai dengan ketentuan sebagaimana dimaksud pada ayat (2)."

Direksi bertanggung jawab secara renteng dalam pasal di atas berarti masingmasing anggota direksi memiliki tanggung jawab, dan pihak yang dirugikan dapat menuntut ganti rugi dari anggota direksi atas keseluruhan jumlah kerugian yang dideritanya. ${ }^{58}$ Kerugian perseroan yang disebabkan kelalaian direksi dalam menjalankan kewajiban atau melanggar larangan atas kepengurusan, direksi bertanggung jawab penuh secara pribadi (persoonlijk aansprakelijk, personally liable $)^{59}$ atas kerugian tersebut.

56 Pasal 92 ayat (2) dan Penjelasannya menyatakan: "Direksi berwenang menjalankan pengurusan sebagaimana dimaksud pada ayat (1) sesuai dengan kebijakan yang dipandang tepat, dalam batas yang ditentukan dalam undang-undang ini dan/atau anggaran dasar." Yang dimaksud dengan "kebijakan yang dipandang tepat" adalah kebijakan yang antara lain didasarkan pada keahlian, peluang yang tersedia, dan kelaziman dalam dunia usaha yang sejenis.

57 Wahyono Darmabrata, "Implementasi Good Corporate Governance dalam Menyikapi Bentuk-Bentuk Penyimpangan Fiduciary Duty Direksi dan Komisaris Perseroan Terbatas", Jurnal Hukum Bisnis, Volume 22, Nomor 6, 2003, hlm. 30.

58 Sutan Remy Sjahdeini, Tugas, Wewenang dan Tanggung Jawab Direksi dan Komisaris BUMN Perseroan, http://wordpress.com, diakses pada tanggal 23 Maret 2012.

Prof. Dr. Sutan Remy Sjahdeini, S.H., FCBArb adalah Guru Besar Universitas Indonesia dengan bidang keahlian Hukum Bisnis.

59 M. Yahya Harahap, Hukum Perseroan Terbatas, Op.cit., hlm. 384. 
Pada Pasal 97 UU PT diatur bahwa kepengurusan yang dipercayakan kepada direksi harus dilaksanakan dengan itikad baik dan penuh tanggung jawab. Apabila direksi terbukti salah atau lalai dalam menjalankan kepengurusannya (beritikad tidak baik) mengakibatkan perseroan rugi, pemegang saham yang mewakili minimal $1 / 10$ bagian dari jumlah seluruh saham dengan hak suara yang sah, ${ }^{60}$ sesuai ketentuan yang ada berhak menggugat direksi bersangkutan untuk dimintai pertanggungjawaban secara penuh dengan mengajukan gugatan ke pengadilan negeri.

Direksi juga dapat dimintai pertanggungjawaban dalam hal perusahaan pailit apabila direksi terbukti memenuhi semua syarat sebagaai berikut: ${ }^{61}$

a. Terdapat unsur kesalahan (kesengajaan) atau kelalaian dari direksi (dengan pembuktian biasa);

b. Untuk membayar utang dan ongkos-ongkos kepailitan, haruslah diambil terlebih dahulu dari aset-aset perseroan. Apabila aset perseroan tidak memenuhi barulah diambil dari aset direksi pribadi; dan

c. Diberlakukan pembuktian terbalik (omkering van bewijslast) bagi anggota direksi yang dapat membutikan bahwa kepailitan perseroan bukan karena kesalahan (kesengajaan) atau kelalaian.

Kriteria dasar dan universal agar suatu piercing the corporate veil secara hukum dapat dijatuhkan adalah sebagi berikut: ${ }^{62}$

a. Terjadinya penipuan;

b. Didapat suatu ketidakadilan;

c. Terjadi suatu penindasan (oppression);

d. Tidak memenuhi unsur hukum (illegal);

e. Dominasi pemegang saham berlebihan; dan

f. Perusahaan merupakan alter ego dari pemegang saham mayoritas.

Penerapan piercing the corporate veil ini pada hakekatnya bertujuan untuk melindungi kepentingan pemegang saham ataupun pihak ketiga yang dirugikan atas tindakan direksi yang sewenang-wenang atau tidak layak yang dilakukan atas nama perseroan. Perbutan yang dilakukan terbit dari suatu transaksi dengan pihak ketiga maupun timbul dari perbuatan menyesatkan atau perbuatan melawan hukum.

Direksi dapat dikenakan piercing the corporate veil apabila direksi melakukan hal-hal sebagai berikut: ${ }^{63}$

a. Direksi tidak melaksanakan fiduciary duty kepada perseroan. Direksi yang dengan sengaja atau lalai dalam menjalankan kewajiban fiduciary duty, tidak bertanggung jawab dan tidak beritikad baik dalam menjalankan pengurusan

\footnotetext{
60 Jono, Hukum Kepailitan, Op.cit., hlm. 65.

61 Ibid., hlm. 24.

62 Ibid.

${ }^{63}$ Munir Fuady, Doktrin-doktrin modern, Op.cit., hlm. 22- 25.
} 
perseroan maka direksi tersebut bertanggung jawab secara pribadi sesuai dengan Pasal 1 angka 5 dan Pasal 97 ayat (3) UU PT. Gugatan terhadap piercing the corporate veil ini dapat dilakukan oleh pihak ketiga yang merasa dirugikan dan/atau pemegang saham yang merasa dirugikan. Pemegang saham bertindak untuk dan atas nama perseroan. Pemegang saham yang diwakikan minimal $10 \%$ dari seluruh saham dan dengan suara yang sah; ${ }^{64}$

b. Dokumen perhitungan tahunan tidak benar. Salah satu tugas direksi adalah menyediakan perhitungan laporan tahunan yang benar, bila terbukti laporan tahunan tersebut tidak benar maka direksi bersama dengan komisaris bertanggung jawab secara renteng berdasarkan doktrin piercing the corporate veil $^{65}$ sesuai denga ketentuan Pasal 69 ayat (3) UU PT. Pada Pasal 69 ayat (4) UU PT diberikan pembuktian terbalik oleh direksi dan komisaris; dan

c. Direksi bersalah dan menyebabkan perusahaan pailit:

1) Terdapat unsur kesalahan (kesengajaan) atau kelalaian dari direksi (dengan pembuktian biasa);

2) Untuk membayar utang dan ongkos-ongkos kepailitan, haruslah diambil terlebih dahulu dari aset-aset Perseroan. Apabila aset perseroan tidak memenuhi, barulah diambil dari aset direksi pribadi; dan

3) Diberlakukan pembuktian terbalik (omkering van bewijslast) bagi anggota direksi yang dapat membutikan bahwa kepailitan perseroan bukan karena kesalahan (kesengajaan) atau kelalaian. ${ }^{66}$

Direksi dapat lepas dari tanggung jawab apabila direksi tersebut dapat membuktikan bahwa ia tidak bersalah sesuai dengan Pasal 104 dan Pasal 115 ayat (1) UU PT:

a. Permodalan yang tidak layak. Manakala modal perseroan tidak cukup layak untuk menunjang suatu kegiatan, maka kegiatan tersebut wajib untuk tidak dilakukan oleh direksi; ${ }^{67}$ dan

b. Perseroan beroperasi secara tidak layak. Apabila perseroan tidak beroperasi secara tidak layak sehingga merugikan pihak ketiga dan/atau pemegang saham, maka direksi bertanggung jawab sebagai pihak eksekutif perseroan berdasarkan doktrin fiduciary duty, kecuali apabila ia telah menjalankan tugasnya dengan benar sesuai dengan prinsip-prinsip (business judgement rule). ${ }^{68}$

\footnotetext{
64 Pasal 97 ayat (6) UU PT yang berbunyi :" (6) Atas nama Perseroan, pemegang saham yang mewakili paling sedikit $1 / 10$ (satu persepuluh) bagian dari jumlah seluruh saham dengan hak suara dapat mengajukan gugatan melalui pengadilan negeri terhadap anggota Direksi yang karena kesalahan atau kelalaiannya menimbulkan kerugian pada Perseroan".

${ }^{65}$ Munir Fuady, Op.cit., hlm. 23.

66 Ibid., hlm. 24.

67 Ibid.

68 Ibid.
} 
Pada Pasal 45 KUHD ditentukan bahwa para pengurus tidak bertanggung jawab lebih daripada untuk menunaikan sebaik-baiknya tugas yang diberikan kepadanya; mereka tidak bertanggung jawab secara pribadi terhadap pihak ketiga atas perikatan perseroan. Apabila mereka melanggar suatu ketentuan dalam akta atau perubahan syarat-syaratnya yang diadakan kemudian, maka mereka bertanggung jawab masing-masing secara tanggung renteng untuk keseluruhannya atas kerugian-kerugian yang diderita oleh pihak ketiga karenanya.

Direksi juga dapat dijerat dengan Pasal 1365 dan 1366 KUHPerdata. Pada Pasal 1365 KUHPerdata disebutkan bahwa setiap perbuatan yang melanggar hukum dan membawa kerugian kepada orang lain, diwajibkan orang yang menimbulkan kerugian itu karena kesalahannya untuk menggantikan kerugian tersebut. Pada Pasal 1366 KUHPerdata juga ditegaskan bahwa setiap orang bertanggung jawab, bukan hanya atas kerugian yang disebabkan perbuatan-perbuatannya, melainkan juga atas kerugian yang disebabkan kelalaian atau kesembronoannya. Kedua pasal di atas merupakan dasar seseorang untuk dijerat berdasarkan prinsip perbuatan melawan hukum (onrechtmatige daad). Pada pasal tersebut ditegaskan mengenai seseorang yang melanggar hukum dalam hal ini UU PT dan ADRT PT yang bersangkutan wajib mengganti kerugian kepada pihak yang dirugikan karena kesembronoannya atau kelalaiannya.

Selain dapat dijerat dengan perkara perdata, kelalaian maupun kesalahan dari direksi tersebut dapat jua dijerat dengan ketentuan pidana melalui Pasal 398 dan Pasal 399 KUHP. Pada Pasal 398 KUHP dinyatakan bahwa seorang pengurus atau komisaris perseroan, maskapai andil Indonesia atau perkumpulan koperasi yang dinyatakan dalam keadaan pailit atau yang diperintahkan penyelesaian oleh pengadilan, diancam dengan pidana penjara paling lama satu tahun empat bulan:

1. jika yang bersangkutan turut membantu atau mengizinkan untuk melakukan perbuatan-perbuatan yang bertentangan dengan anggaran dasar, sehingga oleh karena itu seluruh atau sebagian besar dari kerugian diderita oleh perseroan, maskapai, atau perkumpulan;

2. jika yang bersangkutan dengan maksud untuk menangguhkan kepailitan atau penyelesaian perseroan, maskapai atau perkumpulan, turut membantu atau mengizinkan peminjaman uang dengan syarat-syarat yang memberatkan, padahal diketahuinya tak dapat dicegah keadaan pailit atau penyelesaiannya; dan

3. jika yang bersangkutan dapat dipersalahkan tidak memenuhi kewajiban yang diterangkan dalam Pasal 6 ayat (1) Kitab Undang-undang Hukum Dagang dan Pasal 27 ayat (1) Ordonansi tentang Maskapai Andil Indonesia, atau bahwa buku-buku dan surat-surat yang memuat catatan-catatan dan tulisan-tulisan yang disimpan menurut pasal tadi, tidak dapat diperlihatkan dalam keadaan tak diubah. 
Pasal 399 KUHP menambahkan bahwa seorang pengurus atau komisaris perseroan, maskapai andil Indonesia, atau perkumpulan koperasi yang dinyatakan dalam keadaan pailit atau yang penyelesaiannya diperintahkan oleh pengadilan, diancam dengan pidana penjara paling lama tujuh tahun, jika yang bersangkutan mengurangi secara curang hak-hak pemiutang dari perseroan, maskapai atau perkumpulan untuk:

1. membuat pengeluaran yang tak ada, maupun tidak membukukan pendapatan atau menarik barang sesuatu dari budel;

2. telah melijerkan (verureemden) barang sesuatu dengan cuma-cuma atau jelas di bawah harganya;

3. dengan sesuatu cara menguntungkan salah seorang pemiutang di waktu kepailitan atau penyelesaian, ataupun pada saat di mana diketahuinya bahwa kepailitan atau penyelesaian tadi tak dapat dicegah;

4. tidak memenuhi kewajiban mengadakan catatan menurut Kitab Undangundang Hukum Dagang atau Pasal 27 ayat (1) Ordonansi tentang Maskapai Andil Indonesia, dan tentang menyimpan dan memperlihatkan buku-buku, surat-surat dan tulisan-tulisan menurut pasal-pasal itu.

Pada Pasal 398 KUHP dapat disimpulkan bahwa direksi maupun komisaris dapat dituntut pidana penjara selama satu tahun empat bulan (1 tahun 4 bulan) apabila direksi maupun komisaris menyebabkan kerugian bagi perseroan maupun pihak lain. Menurut Pasal 399 KUHP direksi maupun komisaris dapat dijerat dengan pidana penjara selama tujuh tahun apabila yang bersangkutan membuat kecurangan dengan mengurangi hak-hak para kreditor dan lalai dalam membuat pembukuan sebagaimana diwajibkan dalam anggaran dasar dan peraturan perundang-undangan.

\section{F. Penutup}

Perseroan merupakan artificial person dan memerlukan organ dalam melakukan hak dan kewajibannya. Hukum perseroan di Indonesia menganut sistem separate legal entity (entitas yang terpisah) dan limited liability (tanggung jawab terbatas). Kekayaan dan tanggung jawab dari perseroan terpisah dengan para pendiri dan pengurusnya. Para pendiri dan pengurus disebut sebagai organ perseroan, yaitu RUPS, direksi, dan komisaris. Direksi memegang posisi yang sangat penting. Nasib perseroan dipertaruhkan di tangan direksi karena direksi yang menjalankan kepengurusan dan mewakili perseroan dalam semua tindakannya perseroan.

Direksi perseroan dalam menjalankan pengurusan perseroan dilandasi oleh amanah yang diberikan oleh perseroan. Amanah ini dinamakan fiduciary duty, yang mengahruskan direksi berhati-hati dan beritikad baik dalam menjalankan pengurusannya. Wewenang yang dimiliki direksi harus dijalankan sesuai dengan maksud dan tujuan perseroan yang terdapat dalam ADRT PT dan peraturan 
perundang-undangan. Apabila direksi bertindak melampaui batas kewenangannya, tindakan direksi tersebut menjadi tindakan ultra vires. Akibat dari ultra vires, tindakan tersebut batal demi hukum dan pihak yang dirugikan dapat meminta pertanggungjawaban direksi yang bersangkutan. Hal tersebut membuat tanggung jawab direksi menjadi tidak terbatas dengan terkoyaknya cadar perseroan (piercing the corporate veil).

Pertanggungjawaban oleh direksi tidak hanya sebatas pertanggungjawaban perdata tetapi juga pertanggungjawaban pidana. Adapun pasal-pasal yang dapat digunakan untuk meminta pertanggungjawaban direksi adalah:
a. Pasal 92 ayat (1) dan (2) UU PT;
b. Pasal 97 ayat (2) UU PT;
c. Pasal 104 ayat (2) UU PT;
d. Pasal 1365 KUHPerdata;
e. Pasal 1366 KUHPerdata;
f. Pasal 398 KUHP; dan
g. Pasal 399 KUHP.

\section{Daftar Pustaka}

\section{Buku}

Ahmad Yani, Seri Hukum Bisnis Perseroan Terbatas, Jakarta, Rajawali Pers, 1999.

Chatamarrasjid Ais, Penerobosan Cadar Perseroan dan Soal-soal Aktual Hukum Perusahaan, Jakarta,Citra Aditya Bakti, 2004.

Chidir Ali, Badan Hukum, Bandung, Alumni, 1987.

Freddy Harris \& Teddy Anggoro, Hukum Perseroan Terbatas Kewajiban Pemberitahuan oleh Direksi, Bogor, PT Ghalia Indonesia, 2010.

Gunawan Widjaja, Tanggung Jawab Direksi atas Kepailitan, Cetakan Kedua, Jakarta, PT Raja Grafindo Persada, 2004.

Jono, Hukum Kepailitan, Cetakan ketiga, Edisi Kesatu, Jakarta, Sinar Grafika, 2008.

M. Yahya Harahap, Hukum Perseroan Terbatas, Catakan Ketiga, Edisi Ketujuh, Jakarta, Sinar Grafika, 2011.

M. Hadi Subhan, Hukum Kepailitan, Prinsip, Norma dan Praktik di Peradilan, Jakarta, Edisi Pertama, Cetakan ke-1, Prenada Media Group, 2008.

Marwan, Kamus Hukum Dictionary Of Law Complete Edition, Cetakan Kesatu, Surabaya, Reality Pubilser, 2009.

Munir Fuady, Doktrin-doktrin Modern dalam Corporate Law dan Eksistensinya Dalam Hukum Indonesia, Cetakan Kedua, Bandung, PT. Citra Aditya Bakti, 2010. Ridwan Khairandy, Perseroan Terbatas Doktrin, Peraturan Perundang-Undangan dan Yurisprudensi, Edisi Revisi, Yogyakarta, Total Media Yogyakarta, 2009. 


\section{Dokumen Lain}

Ridwan Khairandy, "Perseroan Terbatas Sebagai Badan Hukum", Jurnal Hukum Bisnis, Volume 26 Nomor 3, 2007.

Nindyo Pramono, "Perbandingan Perseroan di Beberapa Negara", Kegiatan Pelaksanaan dan Pengembangan Sistem Hukum Nasional Badan Pembinaan Hukum Nasional Kementerian Hukum dan Hak Asasi Manusia RI, 2012, hlm. 15. Dapat diunduh di www.bphn.go.id/data/documents/pk-2012-1.pdf.

Shinta Ikayani Kusumawardani, "Pengaturan Kewenangan, dan Tanggung Jawab Direksi dalam Perseroan Terbatas (Studi Perbandingan Indonesia dan Australia)", Jurnal Magister Hukum Udayana, Volume 2, No 1 Tahun 2013.

Sutan Remi Syahdeni, "Tanggung Jawab Pribdai Direksi dan Komisaris," Jurnal Hukum Bisnis, Volume 14, Juli 2001.

Wahyono Darmabrata, "Implementasi Good Corporate Governance dalam Menyikapi Bentuk-bentuk Penyimpangan Fiduciary Duty Direksi dan Komisaris Perseroan Terbatas", Jurnal Hukum Bisnis, Volume 22, Nomor 6, 2003.

\section{Dukumen Hukum}

Kitab Undang-Undang Hukum Perdata.

Kitab Undang-Undang Hukum Dagang.

Undang-Undang Nomor 40 Tahun 2007 tentang Perseroan Terbatas. 